\title{
On the estimation of maximum surface temperature for cells
}

\author{
Marius Darie $^{1 *}$, Tiberiu Csaszar ${ }^{1}$, Adriana Andriș ${ }^{1}$, and Ioana Ciobanu ${ }^{2}$ \\ ${ }^{1}$ National Institute for Mine Safety and Protection to Explosion - INSEMEX, Department for Safety \\ of Installations and Explosion-proof Equipment, 32-34 G-ral Vasile Milea, Petroșani, Romania \\ ${ }^{2}$ Technical University of Cluj-Napoca, Faculty of Automation and Computer Science, \\ St. Memorandumului 28, Cluj-Napoca 400114
}

\begin{abstract}
In paperwork is presented the estimation of the maximum surface temperature of cells exposed to specific tests for the intrinsic safety type of protection. Particularly, it presents the thermal resistance of the short-circuit test-stand results. The first part introduces the aspects regarding the risk of explosion. The risk of explosion occurs due to the presence of technical equipment in areas where flammable substances may occur. The second part itemizes the requirements for the testing of cells. Also, is introduced the stand configuration and performance aspects. The third part of the paper has been dedicated to the presentation and the discussion of the obtained results. The analysis of the test results highlighted the range of thermal resistance. This result could help estimation of the surface temperature of cells based on their capacity and internal resistance. The convection coefficients were determined. The process of deep discharge destroys the inner electrochemical of the cell system. Therefore, it permits energy recovery lower than a fraction of a tenth.
\end{abstract}

\section{Introduction}

In the field of technology, there is a growing need for efficiency, flexibility, and safety. For this purpose, information systems play an important role.

The increasing demand for mobility has increased the need for wireless communications and the independence of equipment from electricity networks.

Technological installations frequently involve flammable substances, which is why hazardous explosive areas are formed [1]. Access to the European market for equipment intended for use in potentially explosive atmospheres is governed by European Directive 2014/34 / EU (2014) [2]. This directive mentions the technical characteristics which highlight the qualification (categories) of explosion protection of the equipment. For electrical equipment, the specific requirements are detailed by specific standards [3].

"Low current equipment and installations" [4] are equipment and installations that use electricity to transfer information. They must comply with the specific requirements for operation in the endangered area of substantial flammable presence [5-7].

\footnotetext{
* Corresponding author: Marius.Darie@insemex.ro
} 
The risk of explosion involved by the presence of technical equipment in potentially explosive atmospheres could be determined by spark ignition $[8,9]$ of electrical equipment, electrostatic discharge, and mechanical impact, etc. [10,11]. Similarly, mixtures of air with flammable substances can be ignited from hot surfaces [12-14].

The intrinsic safety type of protection acts on the electrical and thermal sources to suppress their capacity of ignition [4]. In addition, the intrinsic safety type of protection specifically implements a strategy that takes into account component failures, connections, and circuit breakdowns.

Possible explosion protection scenarios are taken into account in the design phase. Such scenarios take into account both normal operation and malfunction. Thus, the requirements of the ATEX Directive regarding the classification in categories $(1,2$, or 3$)$ and also the requirements of the IEC standard for levels of protection (a, b, and c) are implemented [4].

For the explosion-protected equipment with intrinsic safety type of protection, an important aspect is an ignition due to hot surfaces.

A specific case of ignition from hot surfaces is cells and batteries. Those are considered capable of ignition if an internal short-circuit occurs.

To highlight the maximum value of surface temperature for the cells, the specific standard [4] includes the short-circuit test for the cells.

Even, for some tests, the specific standard offers an alternate calculus method, for the maximum surface temperature test of the cells it is not offered an alternative.

$\mathrm{O}$ the other hand, due to complexity of the system comprised of the environment (air), test stand (short-circuiting device), and inner electrochemical system of the cells makes an estimation difficult.

The paper address especially heats exchange between cells under test and the environment.

\section{Material and methods}

To support mobility, the cells are used in portable devices intended for communications, various measurements, etc. These cells can be primary cells (which cannot be recharged) or secondary cells (which can be recharged) [7]. Supercapacitors are also addressed in the specific standard [4] in the same way as cells.

The required tests by the specific standard for the intrinsic safety type of protection cover the risk of spark ignition and the risk of thermal ignition (Figure 1). The maximum temperature test requires ten samples that are short-circuited and the maximum surface temperature is recorded.

This test provides two results, the maximum temperature reached in the test process and the maximum short-circuits current.
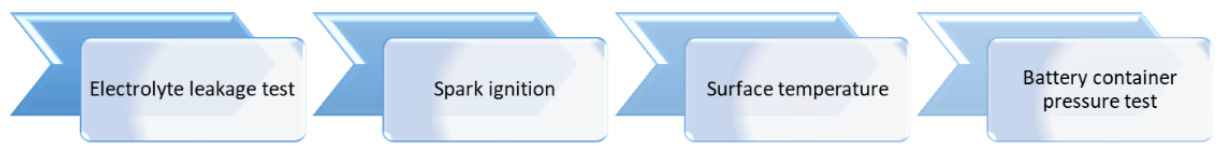

Figure 1. Tests of cells

These tests show that the cells being subjected to the most adverse conditions (short circuit), do not heat up in such a way that the temperature reaches a dangerous threshold. An additional test result is a maximum current. Another aspect highlighted by the test is preserving the integrity of the electrochemical container of the cell to avoid electrolyte leakage. 
The test stand contains a short-circuiting device, a temperature sensor, and a current probe connected to the data recording system (Figures 2 and 3). The specific standard requires that for the short-circuit connection device (excluding connections to it) either the resistance not to exceed $3 \mathrm{~m} \Omega$, or the voltage drop not to exceed $0.2 \mathrm{~V}$ or $15 \%$ of the electromotive force of the cell.

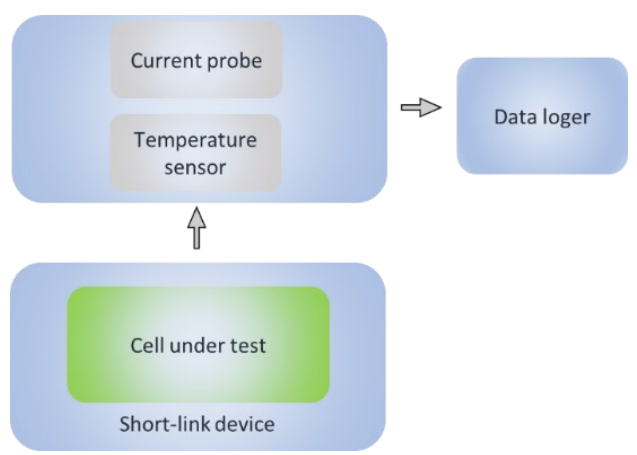

Figure 2. Block diagram of the test stand

To measure the temperature rise relative to the ambient temperature it was necessary of using the second temperature sensor for the ambient temperature.

Given the observed temperature dynamics, it was considered that the time resolution of one second (in the data recording process) is satisfactory for thermal monitoring.

\section{Results and discussions}

The temperature measurements done for 10 cells were recorded and the difference to the ambient temperature is presented in Figure 3. The measured ambient temperature was $24^{\circ} \mathrm{C}$.

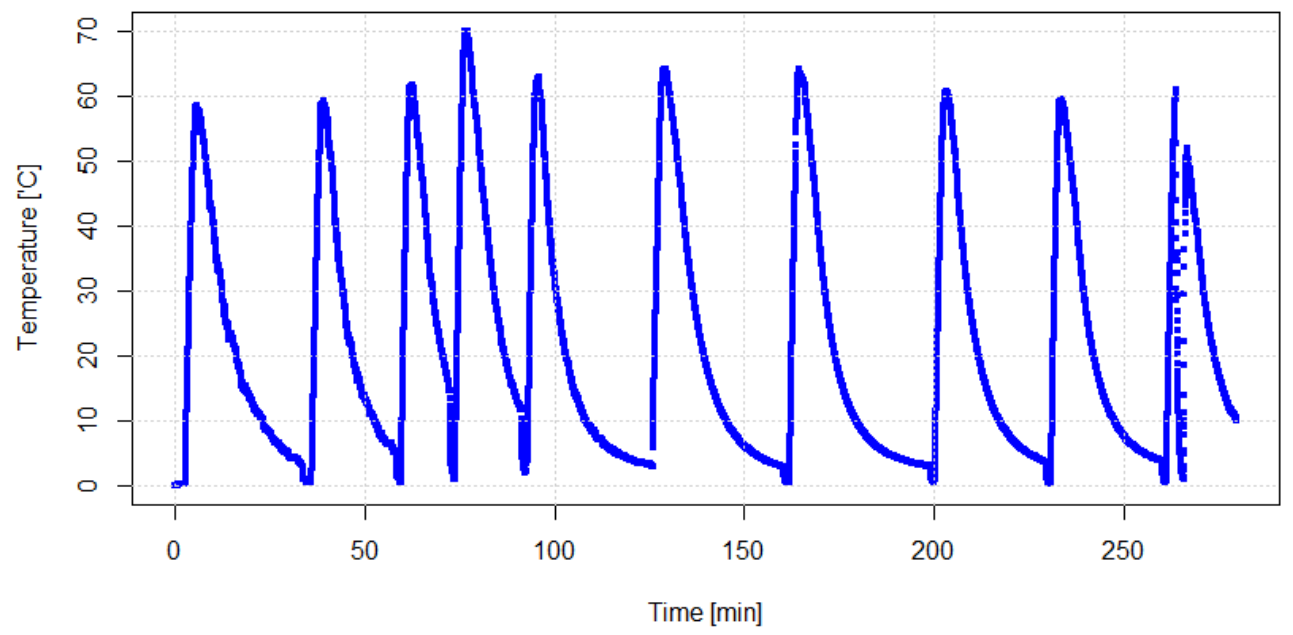

Figure 3. Meassured temperature of the cells relative to ambient temperature

Through discharging by short-circuiting the cells are getting hotter. The short-circuit is switched off after the cell reaches the maximum temperature. Subsequently, the cells were left to cool due to the convection and conduction. 
In figure 4 is presented the logarithm of the cell temperature in the cooling phase with respect to time. It could be observed that linear regression is a good approximation but for the first step, quadratic regression was used. Due to the discharge fluctuation, the tenth element was omitted from the following analysis. The obtained coefficients for the quadratic regression are presented in table 1 .

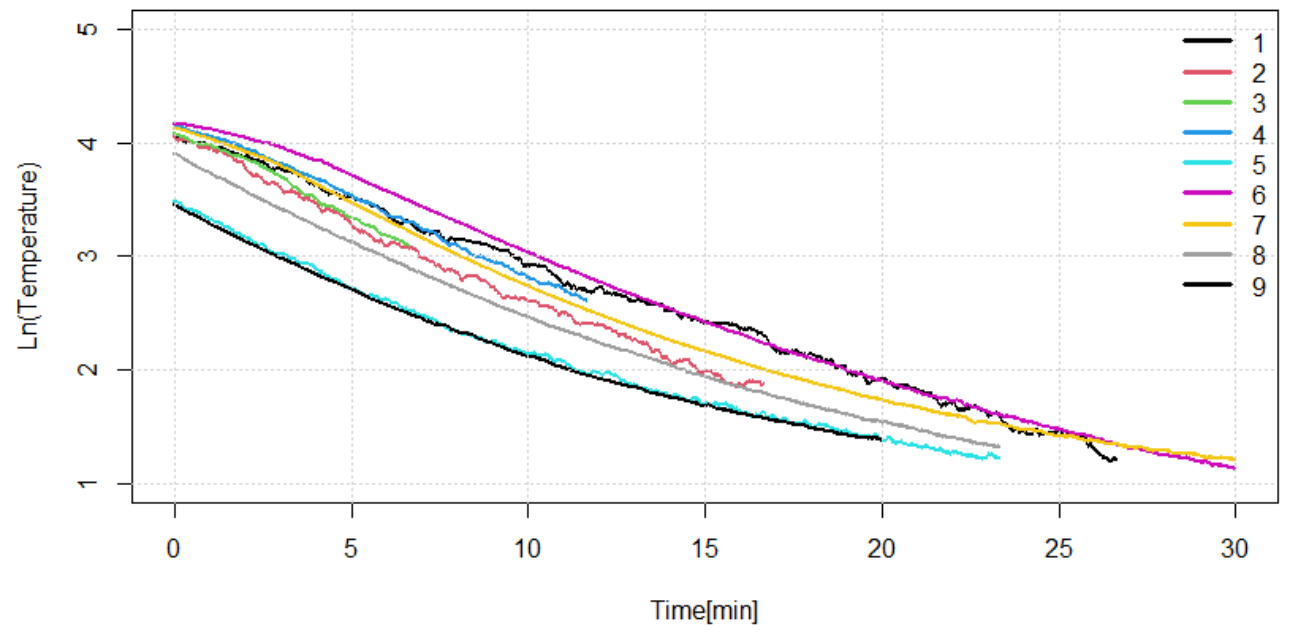

Figure 4. The logarithm of temperature as a function of time for the stage of cooling

Table 1. The quadratic regression coefficients

\begin{tabular}{|c|c|c|c|}
\hline Element & $\mathbf{c}$ & $\mathbf{b}$ & $\mathbf{a}$ \\
\hline $\mathbf{1}$ & 4.084 .014 & -0.1185101 & 0.0004726090 \\
\hline $\mathbf{2}$ & 4.095 .537 & -0.1697561 & 0.0020438585 \\
\hline $\mathbf{3}$ & 4.097 .269 & -0.1238723 & -0.0047621391 \\
\hline $\mathbf{4}$ & 4.194 .989 & -0.1302067 & -0.0006608786 \\
\hline $\mathbf{5}$ & 3.466 .221 & -0.1580116 & 0.0026983256 \\
\hline $\mathbf{6}$ & 4.349 .976 & -0.1456826 & 0.0012340969 \\
\hline $\mathbf{7}$ & 4.255 .457 & -0.1756993 & 0.0024853508 \\
\hline $\mathbf{8}$ & 3.899 .032 & -0.1673721 & 0.0024598016 \\
\hline $\mathbf{9}$ & 3.444 .534 & -0.1616171 & 0.0029511726 \\
\hline Mean & 3.987 .448 & -0.1500809 & 0.0009913553 \\
\hline
\end{tabular}

The heat loss to the environment due to convection is presented in equation (1)

$$
Q_{2}(t)=k_{2}\left(T(t)-T_{\infty}\right)^{b}
$$

The $\mathrm{b}$ and $\mathrm{k}_{2}$ are coefficients, $\mathrm{T}(\mathrm{t})$ is the temperature of the cell and $\mathrm{T}_{\infty}$ ist the ambient temperature.

The caloric capacity of the cell is computed using equation (2)

$$
Q_{0}(t)=k_{0}\left(T(t)-T_{\infty}\right)
$$

Additionaly to symbols in equation (1) the $\mathrm{k}_{0}$ is a coefficient.

The heat internally generated in the cell due to short-circuit is described by equation (3) 


$$
\dot{Q}_{1}(t)=P(t)
$$

After the temperature reaches the maximum value due to short-circuit of the cell, the shortcircuit link is switched off and the cell gets cool due to the heat loss.

The heat balance of the system is described by equations (4)

$$
Q_{1}(t)=Q_{0}(t)+Q_{2}(t), \dot{Q}_{1}(t)=\dot{Q}_{0}(t)+\dot{Q}_{2}(t)
$$

Considering the cooling phase, the temperature variation with respect to time is described by equations $(5)$

$$
T(t)=e^{\bar{a} \cdot t^{2}+\bar{b} \cdot t+\bar{c}}, \dot{T}(t)=(\bar{a} \cdot t+\bar{b}) T(t)
$$

where bar coefficients denote the mean values.

In the cooling phase the heat balance is presented in the equations (6).

$$
Q_{1}(t)=0,0=Q_{0}(t)+Q_{2}(t)
$$

Using logarithm, the equation (6) can be rewrited as equation (7)

$$
\ln (-\dot{T}(t))=\ln \left(k_{2} / k_{0}\right)+b \cdot \ln \left(T(t)-T_{\infty}\right)
$$

In the equations above, $\mathrm{T}$ is the cell temperature, $\mathrm{T}_{\infty}$ is environment temperature, $\mathrm{k}$ and $\mathrm{b}$ are coefficients, $\mathrm{P}$ is the internal power dissipation in the cell due to the short-circuit, and a,b,c are quadratic regresssion coefficients.

By using the linear regression (figure 5) the coefficients $b$ and $k_{2} / \mathrm{k}_{0}$, are obtained. The obtained values are: $\mathrm{b}=1.096965$ and $\mathrm{k}_{2} / \mathrm{k}_{0}=0.110484$.

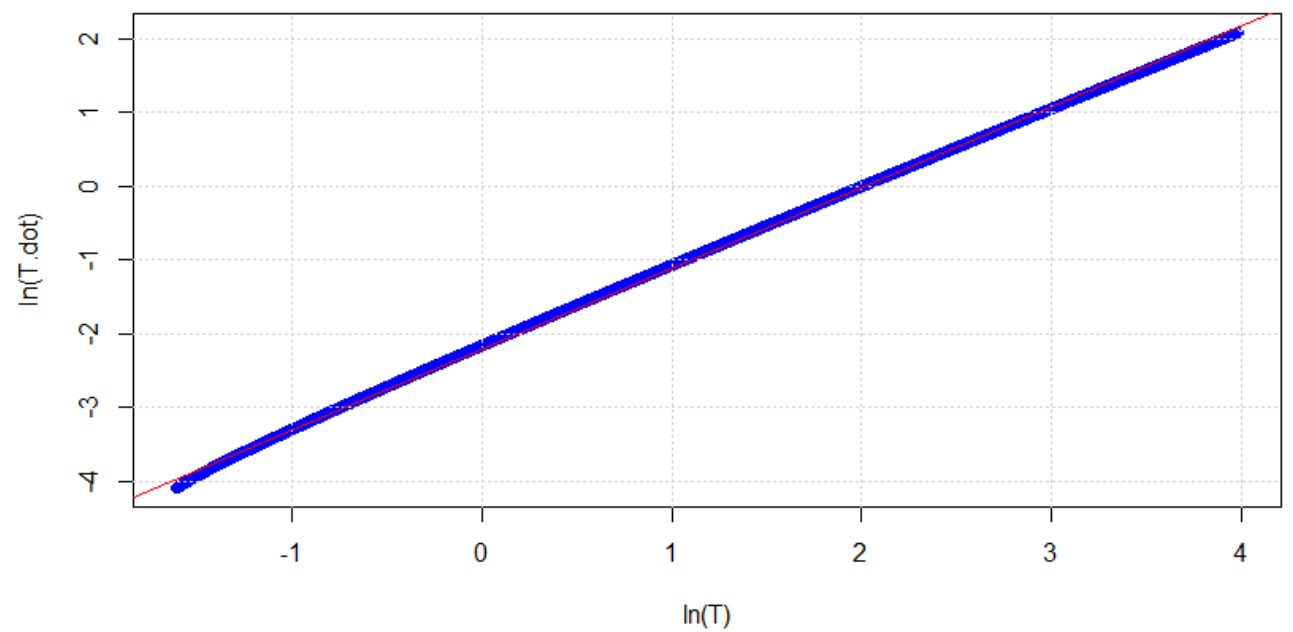

Figure 5. The liniar regression according equation (7)

The generated heat in the cell due to the short circuit could be computed using equation (9).

$$
\dot{Q}_{1}(t)=P(t)=r \cdot I(t)^{2}
$$

Where $r$ is the internal resistance of the cell (about $50 \mathrm{~m} \Omega$ ), and $\mathrm{I}(\mathrm{t})$ is the cell curent meassured in A.

Considering equations (1), (2), (4) and (9) is obtained the equation (10) 


$$
\int_{0}^{t} r \cdot I(\tau)^{2} d \tau=k_{0}\left(T(t)-T_{\infty}\right)+k_{2}\left(T(t)-T_{\infty}\right)^{b}
$$

To find the coefficients $\mathrm{k}_{0}$ and $\mathrm{k}_{2}$, the heat generated by the cell was computed based on measured current values and internal resistance of the cell $(\mathrm{r}=50 \mathrm{~m} \Omega)$.

The average heat generated in the cell is $Q_{1}=860 \mathrm{~J}$ and the average discharge time is $252 \mathrm{~s}$. The confirmed capacity of the cell is $25 \%$ of nominal value $(2000 \mathrm{mAh})$ and generated energy in the cell is $6 \%$ of nominal value $(3.9 \mathrm{Wh})$. The observed low ratio compared to nominal values is due to the damages that occurred in the cell due to the overheating.

Consequently, based on the heat balance mentioned in equation (10) the resulted values are $\mathrm{k}_{0}=6.09305 \mathrm{~J} / \mathrm{K}$ and $\mathrm{k}_{2}=0.6731845 \mathrm{~J} / \mathrm{K}$.

For performing the calculus and diagrams were used the $\mathrm{R}$ language and $\mathrm{R}$ Studio environment $[15,16]$.

\section{Conclusions}

The process of deep discharging (short circuit) of the cells involves a heating process. For the tested cells, the highest recorded temperature was near $90^{\circ} \mathrm{C}$.

The cooling phase of the cells follows a law of heat transmission by convection.

The convection coefficients were determined. These coefficients are dependent on the stand structure.

The coefficient for the heat capacity of the cells includes the heat conducted through electrical connection plots too.

The process of deep discharge destroys the inner electrochemical system permits recovery just of $6 \%$ of the stored energy.

\section{References}

1. D. Cioclea, A.G. Găman, I. Gherghe, F. Rădoi, C. Boantă, V. Pasculescu, Possibilities to priorly establish the structures of ventilation networks affected by underground explosions, The 24th International Mining Congress and Exhibition of Turkey, 14 - 17 April 2015, Antalya, Turcia, ISBN 978-605-01-0705-0, pp 991-997 (2015).

2. ATEX Directive, Equipment for potentially explosive atmospheres (ATEX), available https://ec.europa.eu/growth/sectors/mechanical-engineering/ atex en (2014).

3. V.M. Păsculescu, N.I. Vlasin, D. Florea, M.C. Suvar, Improving the quality of the process for selecting electrical equipment intended to be used in potentially explosive atmospheres, Quality - Access to Success, Romania, vol. 18/issue S1, pp 97-102 (2017).

4. (SR) EN 60079-11: 2012 - Explosive atmospheres Equipment protection by intrinsic safety "i", (2012).

5. V.M. Păsculescu, M.C. Suvar, N.I. Vlasin, G.A. Găman, D. Florea, Computer modelling of flammable gas dispersion through leakages occurred in technological installations, 15th International Multidisciplinary Scientific GeoConference SGEM 2015, www.sgem.org, SGEM2015 Conference Proceedings, ISBN 978-619-7105-34-6 / ISSN 1314-2704, June 18-24, 2015, Book 2 Vol. 1, Albena, Bulgaria, pp. 77-84 (2015).

6. M. Prodan, E. Ghicioi, C. Lupu, I. Nălboc, A. Szollosi-Mota, Flammability characterisation of a petroleum derivative for increasing the safety of personnel and environmental protection, International Multidisciplinary Scientific GeoConference: SGEM; Sofia, Vol. 4 (2016).

7. (SR) EN 60079-0: 2013 - Explosive atmospheres - Part 0: Equipment - General requirements (2013).

8. M. Darie, J. Ionescu, S. Burian, T. Csaszar, L. Moldovan, Ignition probability assessment of low current circuits designed for use in explosive atmospheres, Environmental Engineering and Management Journal, volume 11/2012, No.5 (2012). 
9. M. Prodan, M. Mitu, D. Razus, D. Oancea, Spark ignition and propagation properties of methaneair mixtures from early stages of pressure history, Revue Roumaine de Chimie, 61(4-5), pp 299305 (2016).

10. M. Prodan, L.A. Lupu, E. Ghicioi, I. Nalboc, A. Szollosi-Mota, Pyrophoric sulfides influence over the minimum ignition temperature of dust cloud, AIP Conference Proceedings 1918, 020001, https://doi.org/10.1063/1.5018496 (2017).

11. (SR) EN 1127-1: 2019 - Explosive atmospheres. Explosion prevention and protection. Basic concepts and methodology (2019).

12. E. Ghicioi, I.C. Jitea, N.I. Vlasin, A. Kovacs, G. Vasilescu, et al., Computational study in the civil use explosives area, International Multidisciplinary Scientific GeoConference : SGEM; Sofia Vol. 3: 139-145. Sofia: Surveying Geology \& Mining Ecology Management (SGEM) (2014).

13. L. Moldovan, S. Burian, M. Magyari, M. Darie, D. Fotău, Factors influencing the determination of maximum surface temperature for explosion-proof luminaires, Environmental Engineering and Management Journal, Vol.16, No. 6, pp 1309-1316 (2017).

14. C. Tomescu, M. Prodan, N. Vatavu, E. Chiuzan, Monitoring the work environment using thermal imaging cameras in order to prevent the self-ignition of coal, Environmental Engineering and Management Journal, Vol.16, No. 6, pp 1389-1393 (2017).

15. R Development Core Team (2008). R: A language and environment for statistical computing. R Foundation for Statistical Computing, Vienna, Austria. ISBN 3-900051-07-0, URL http://www.R-project.org.

16. R Core Team (2015). R: A language and environment for statistical computing. R Foundation for Statistical Computing, Vienna, Austria. URL http://www.R-project.org/. 